\title{
Topography and syntopy of abdominopelvic viscera of the giant anteater (Myrmecophage tridactyla - Linnaeus, 1758)
}

[Topografia e sintopia das vísceras abdominopélvicas do tamanduá-bandeira (Myrmecophage tridactyla - Linnaeus, 1758)]

\author{
F.R. Oliveira ${ }^{1}$, F.R. Lima $^{1}$, M.J. Silvino ${ }^{2}$, L.F. Pereira ${ }^{2}$, F.G.G. Dias $^{2 *}$ \\ ${ }^{1}$ Aluno de graduação - Universidade de Franca - Franca, SP \\ ${ }^{2}$ Universidade de Franca - Franca, SP
}

\begin{abstract}
In view of the scarcity of data about the topography and syntopy of abdominopelvic viscera of the giant anteater (Myrmecophage tridactyla - Linnaeus, 1758), the present study aimed to elucidate these characteristics and to compare them with the other animal species, especially the domestic ones. Three specimens, two males and one female, were donated by the Environmental Military Police of Franca to the Anatomy Veterinary Laboratory of the University of Franca, after death by road killings. The animals were fixed and maintained in aqueous $10 \%$ formaldehyde solution, followed by conventional dissection of the abdominopelvic cavities for subsequent direct inspection and topographic description of the viscera, aiming at comparative analyzes with other species, whose positioning and particularities are already established in the literature. It was observed that most of the viscera of these cavities have similar location and syntopy to domestic animals, except for the kidneys and testicles. In view of the established methodology and the results obtained, it is accepted that more specimens of anteater, both genera, should be evaluated and registered scientifically to confirm the data of the current research and anatomical preconization of the abdominopelvic cavity, inasmuch anatomical individual variation are possible between animals of the same species.
\end{abstract}

Keywords: animal anatomy, abdominopelvic cavity, organs, xenarthra

\section{RESUMO}

Diante da escassez de dados sobre a topografia e a sintopia das vísceras abdominopélvicas do tamanduá-bandeira (Myrmecophage tridactyla - Linnaeus, 1758), o presente estudo teve como objetivo elucidar essas características e compará-las com as demais espécies animais, mormente as domésticas. Utilizaram-se três espécimes, dois machos e uma fêmea, provenientes de doação da Polícia Militar Ambiental de Franca ao Laboratório de Anatomia Veterinária da Universidade de Franca, após óbitos por atropelamentos. Os animais foram fixados e mantidos em solução aquosa de formaldeído a $10 \%$, seguidos de dissecação convencional das cavidades abdominopélvicas para posterior inspeção direta e descrição topográfica das vísceras, visando a análises comparativas com outras espécies, cujo posicionamento e cujas particularidades já são bem estabelecidos na literatura. Observou-se que a maioria das vísceras dessas cavidades possuem localização e sintopia similares aos animais domésticos, exceto os rins e os testículos. Diante da metodologia estabelecida e dos resultados obtidos, admite-se que mais espécimes de tamanduás-bandeiras, de ambos os gêneros, devam ser avaliados e registrados cientificamente, visando à confirmação dos dados da atual pesquisa e à preconização anatômica da cavidade abdominopélvica, visto que variações anatômicas individuais são passíveis entre animais da mesma espécie.

Palavras-chave: anatomia animal, cavidade abdominopélvica, órgãos, xenarthra

Recebido em 13 de novembro de 2018

Aceito em 29 de dezembro de 2018

*Autor para correspondência (corresponding author)

E-mail: fernanda.dias@unifran.edu.br 


\section{INTRODUCTION}

The giant anteater (Myrmecophage tridactyla Linnaeus, 1758), representative of the suborder Xenarthra and the Pilosa order, it is the largest representative of the Myrmecophagidae Family (Miretzki and Braga, 2014), being found in Southeast Mexico, Central and South America (Ribeiro et al., 2013, Ribeiro et al., 2016), however, in some areas is in extinction (Braga, 2004; Miretzki and Braga, 2014) as a result of environmental destruction such as fires, predatory action by man, illegal traffic and automobile acidentes, besides reproductive and alimentary factors (Medri and Mourão, 2005; Giraldi et al., 2017).

Considering the importance of the organs that compose the abdominopelvic cavity and the constant interest in the creation and preservation of wild animals, the present research had the objective of describing the topography and syntopy of these, since in these giant anteaters, these data are spare in the scientific literature and notwithstanding, to compare them with animal species.

\section{MATERIAL AND METHODS}

The work was carried out with the approval of the Ethics Committee in the Use of Animals (CEUA) of the University of Franca (UNIFRAN - SP) (protocol $\mathrm{n}^{\circ}$ 032/15). Three giante anteaters (Myrmecophage tridactyla) were used, two males and one female, donated by the Environmental Military Police of Franca to the Anatomy Veterinary Laboratory of the University of Franca, after death by road killings. The specimens were fixed by intravenous and intracavitary infusion and kept submerged in aqueous $10 \%$ formalin solution (Neon Comercial Ltda, Brazil), placed in dorsal decubitus on surgical ducts, maintaining in situ the arrangement and distribution of the organs.

Afterwards, the abdominopelvic cavities were submitted to the wide tricotomy followed by the conventional dissection technique (Konig and Liebich, 2016), with the aid of a scalpel blade 24 (Lamedid $^{\circledR}$, Brazil), surgical scissors and forceps (Brasmed - Brazilian Society of Veterinary Surgery Ltda, Brazil) from the xiphoid cartilage to the external genitalia. After that, four quadrants were inserted by insertion of two lines, one longitudinal from the caudal end of the xiphoid process to the cranial border of the pubis in the median line and another transversal traced in relation to the costal of the right antimer on the left, aiming at photographic records and description of the topography and syntopy of the organs. For the naming of the anatomical structures, the terminologies recommended in Nomina Anatomic Veterinary (2012) were used as standard.

\section{RESULTS}

After dissection of the skin layers of the abdominopelvic cavities, we observed the linea alba, umbilical scar and straight musculature of the right and left abdomen. These musculature were incised, together with the parietal peritoneum and the abdominopelvic cavities, noting immediatly the largest omentum, characterized by a thin mesh, covering the viscera, in a generalized manner. Then, the cavities were demarcated in four quadrants (right abdominal cranial (A) and left (B) and right caudal abdominopelvic (C) and left (D) to facilitate the evaluation of topography and syntopy of the viscera (Figure 1). In the abdominal cranial quadrant (A and B), approximately 1 to $2 \mathrm{~cm}$ caudal to the xiphoid process, it was observed the abdominal portion of the esophagus, part of the stomach and small intestine, pancreas, minor omentum, spleen and hepatic lobes as well as gall bladder.

Specifically in the right antimer of this quadrant (A), it was noticed the smaller curvature of the stomach, of the pyloric, antrum, part of the stomach and duodenum, pancreas adhered to the duodenum and part of the medial and lateral hepatic lobes whereas in the left antimer of this quadrant (B), were observed part of the fundus and body of the stomach, greater curvature of the stomach surrounding the medial, lateral hepatic lobes and left quadrant (Figure 1), together with the gall bladder provided with a bile duct and the spleen inserted into the greater curvature of the stomach.

With regard to the caudal abdominal quadrant $(\mathrm{C}$ and D), it was found that it is almost completely filled by the small and large intestine, but a small part of the stomach was also identified in this region, as well as the kidneys, testes, ovaries, uterus and urinary bladder. 
In the right antimer of this quadrant (C) was observed part of the gastric body, ileum and jejunum (Figure 2), and the latter remained fixed in the abdominal cavity by the mesentery. Additionally, the right kidney was considerably caudal in relation to the domestic species, located

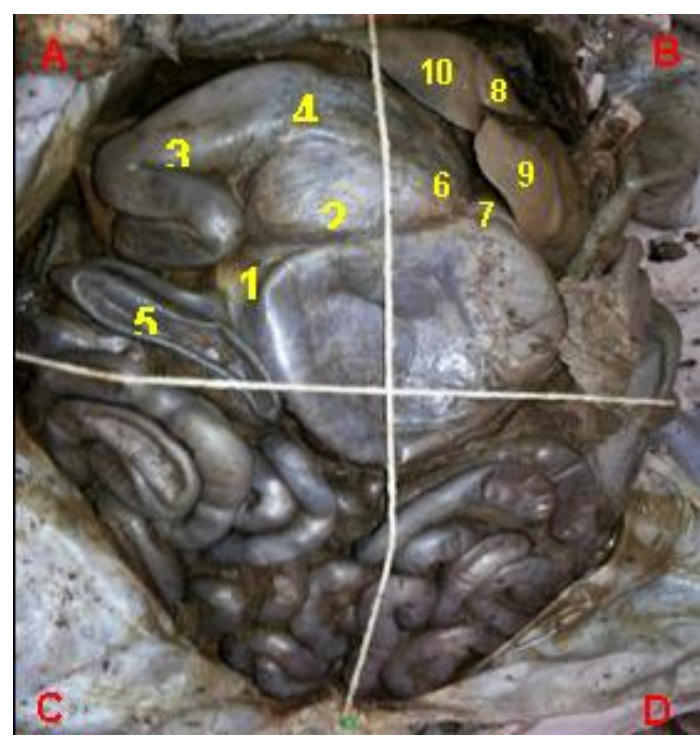

Figure 1. Abdominopelvic cavity of giant anteater. Anatomical structures present in the right (A) and left (B) cranial abdominal quadrant: lower curvature of the stomach (1), part of the body of the stomach (2), pylorus (3), pyloric part (4), duodenum (5), stomach fundus (6), greater stomach curvature (7), left medial hepatic lobe (8), left lateral hepatic lobe (9) and left hepatic lobe (10).

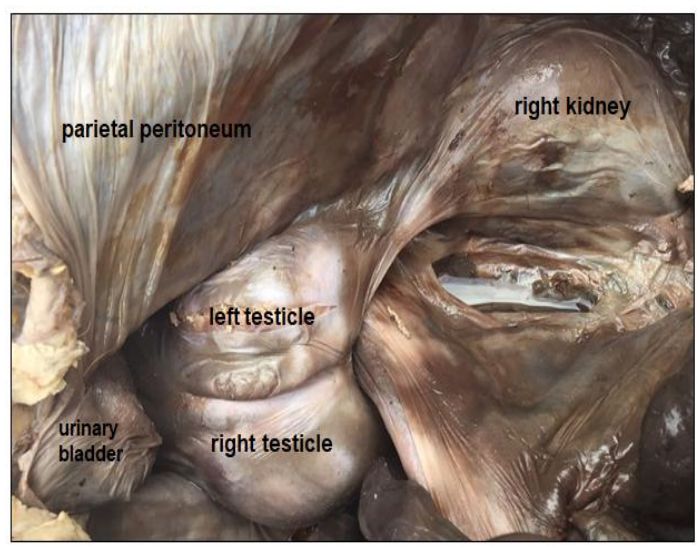

Figure 3. Photographic image of the abdominopelvic cavity of the giant anteater, demonstrating caudal location of the right kidney (near the corresponding testis) and the parietal peritoneum covering these organs. near the testis of the corresponding antimer, in addition to being totally covered by a thick layer of tissue, supposedly the parietal peritoneum (Figure 3). After the removal of the latter structure, it was observed that the right kidney produced rounder and "bean-grain" shapes.

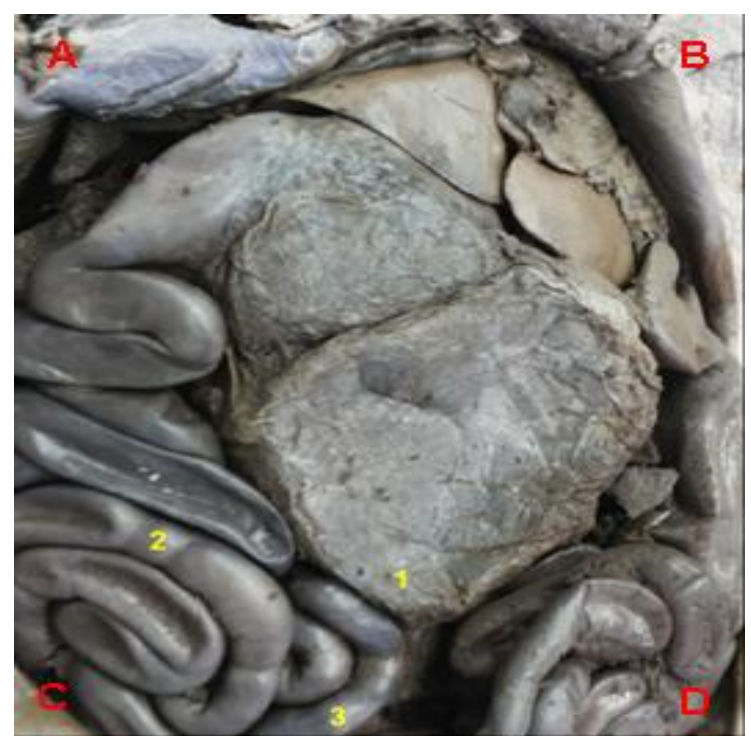

Figure 2. Photographic image of giant anteater, emphasizing the anatomical structures present in the right caudal abdominopelvic quadrant $(\mathrm{C})$ : part of the gastric body (1), jejunum (2) and ileum (3).

The right testicles, also covered by this thick layer of tissue, showed rounded shapes and intracavitary location (Figure 3). The urinary vesicle, located caudally to the testicles (Figure 3 ), presents an elliptical shape, being possible to distinguish externally the regions of the apex, body and colon. As no anatomical structure was dissected, it was not possible to describe some such as the ureters. Every part of the abdominal and pelvic cavity is covered by the parietal peritoneum.

The right ovary, small, with a regular surface and a flat shape, was in direct syntopy with the equivalent antimer's kidney and the uterus (Yshaped) extending from the abdominal to pelvic cavity. In the opposite quadrant (D), was denoted part of the gastric body and jejunum, ileum, cecum, colon (devoid of sacculations), rectum 
and testis, ovary and left kidney. The left testicles also showed similar covering, shape, and location analogous to the right, as well as the ovary.

The left kidneys, also covered by the parietal peritoneum, were located remarkably more caudal than the domestic species, were flattened and in "bean-grain" shape. After dissection, it was observed that, for the renal hilum, the left ones showed rounded shapes, whereas the right ones, in slits (concave) (Figure 4).

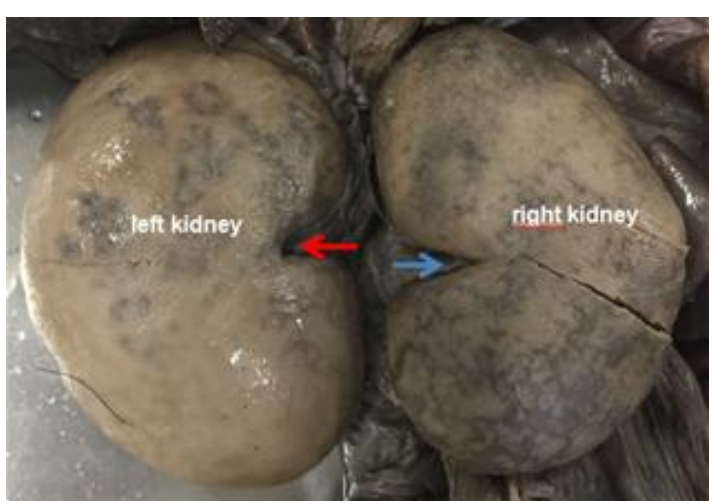

Figure 4. Photographic image of the kidneys of the giant anteater, demonstrating of "bean grain" shape. Left renal hilum rounded (red arrow) and concave right (slit shape) (blue arrow).

\section{DISCUSSION}

Due to the constant interest in the creation and preservation of wild animals, the study of topographic anatomy becomes essential to clarify both the behavioral and evolutionary data of these species (Sesoko et al., 2015; Giraldi et al., 2017), therefore the objective was to describe the comparative morphology and syntopy between the organs that compose the abdominopelvic cavity of the giant anteater, comparing them with the domestic animals. However, the scarcity of anatomical data about the Myrmecophage tridactyla makes morphometric and morphological discussion difficult and restricted. Thus, it is emphasized that descriptions of a larger number of animals should be registered scientifically for the recommendation of the anatomical pattern of the anteater, eliminating individual variations, likely to occur among individuals of the same species.

As described in domestic animals by Getty (1986), Dyce et al. (2010) and Konig and
Liebich (2016), the abdominal portion of the esophagus of the giant anteater is also short and cylindrical and enters the abdominal cavity through the esophageal hiatus, ending in the cardia, even these animals presenting different eating habits. The transition between the esophagus and the stomach does not present any specific and differentiated structure, unlike that found in Anatolian Shepherd dogs (Alsafy and El-Gendy, 2012) and opossums (Bremner et al., 1970).

Corroborating with the descriptions of Pinheiro et al. (2014), it was observed that the stomach of the anteater, located paramedian to the hepatic lobes and caudally to the liver, is unicavitary and saccular, as in monogastric mammals, constituted by cardiac region, fundus, body, pylorus and major and minor curvature. In addition, these researchers also reported that this organ is found in its greater totality in the left antimer of the abdominal cavity, maintaining syntopy with the esophagus (cranially) and with the duodenum (caudally) and that in the pyloric region it is possible to denote the pyloric torus as in cattle and pigs, characterized by increase of pyloric surface, similarly when observed in the three animals of the current research and in the collared anteater. Thus, such topographic, synoptic and macroscopic morphological features are similar to those of domestic and wild animals (Getty, 1986; Dyce et al., 2010; Pinheiro et al., 2014; Konig and Liebich, 2016).

According to Pinheiro et al. (2014), the size and shape of the stomach of the anteaters is related to the insectivorous eating habit. Furthermore, Dyce et al. (2010) reported that torus pyloricus function is not well established, but in this context, Getty (1986) described that this anatomical structure has both active and passive action on the complete closure of the pyloric ostium. Even if the stomach of the giant anteater exhibits similar carnivorous shape, topography and syntopia (Getty, 1986; Konig and Liebich, 2016). Lopes et al. (2015) observed through sonographic images that the wall of this organ in the anteaters is considerably thicker.

In the giant anteater, the larger omentum fixes the stomach to the spleen, intestine and pancreas, as described in chinchillas by Castro et al. (2010); in contrast, these characteristics were not found in the maned sloth (Rezende et al., 2011). 
Still in the giant anteater, it was observed that the smaller omentum stabilizes the stomach to the hepatic lobes, according to reports of Castro et al. (2010) in domestic animals and Carvalho et al. (2012) in paca (Cuniculus paca). In the anteaters of this study, the hepatic localization was observed in the more cranial portion of the abdomen, with syntopy to the diaphragm muscle and stomach, as well as the spleen caudally to the stomach and with regular contours, coinciding with the sonographic findings of Lopes et al. (2015).

There were no discrepancies in the intestine of domestic animals (Getty, 1986; Konig and Liebich, 2016) with that of the anteater, since the abdominal cavity of Myrmecophage tridactyla is almost completely filled by the small intestine, being in the right antimer by the duodenum and jejunum, and in the left by the ileum (Souza et al., 2010), as well as in the collared anteater (Ferreira et al., 2011) and capybara (Freitas et al., 2008). In this context, Gull et al. (2015) have verified that the digestive processes and digestive physiology of the captive giant anteater are similar to the domestic carnivores in relation to nutritional digestibility and digestion retention.

The caecum of the giant anteater is small and has a blind fundus and there are no descriptions in the literature about its function in this species, since in herbivores and omnivores, this anatomical structure increases the retention time and facilitates the fermentation of such species, but doesn't match with the eating habits of the anteaters (Mei et al., 2009).

The colon is extensive, showing no clear distinction between the descending portion and the rectal, as described in domestic animals (Konig and Liebich, 2016) and the absence of sacculations in this intestinal tract was also described in this species by Souza et al. (2010), as well as certified in the current work. In the three cadavers, the right and left kidneys were visualized in the mesogastric region, supporting the reports of Lopes et al. (2015); however, these anatomical structures showed a more caudal projection compared to the carnivores (Getty, 1986; Lopes et al., 2015; Konig and Liebich, 2016), especially the right, differing from the pigs, which present renal symmetry (Konig; Liebich, 2016).
In the present study, the left kidney showed a flattened shape, corroborating with Konig and Liebich (2016) when describing the renal anatomy in the porcine species and, the right, rounded, similar to the carnivores, according to the same authors. In addition, they are totally covered by a layer of thick tissue, probably the parietal peritoneum, a peculiarity not described in the scientific literature in any domestic animal species, until the present moment. The configuration of the left (rounded) renal hilum ratifies with the descriptions made by Getty (1986) and Konig and Liebich (2016) in the canine and feline species, as well as the right (slot) coincides with of the right kidney of the horses. In relation to the peritoneum of the giant anteater, it was observed the non-fixation of the intestinal colon to the dorsal wall of this anatomical structure (Siqueira and Lázaro-daSilva, 2003) as well as commonly seen in other vertebrates (Getty, 1986; Konig and Liebich, 2016).

Scientific information about reproductive parameters of the anteaters are scarce (Luba $e t$ al., 2015). In contrast to that found in domestic animals in relation to the testicular descent (Getty, 1986; Konig and Liebich, 2016), the testes of the anteaters are characterized by intraabdominal position, dorsally to the urinary vesicle and close to the rectum, presenting oval shape, interconnected by peritoneum, similar to the anatomical descriptions of Bartmann et al. (1991) and Hossotani and Luna (2016) and the sonographic findings of Lopes et al. (2015). Thus, the male anteaters are similar to the rabbits, which also have the testicles housed in the abdominopelvic cavity, being externalized at the time of reproduction (Johnson-Delaney, 1996).

In this context, such testicular location associated with the genital cleft (present in both males and females), impairs sexing in the giant anteaters (Lopes et al., 2015; Hossotani and Luna, 2016). As for the accessory sex glands of the males, Bartmann et al. (1991) affirmed that the anteater has the prostate, vesicular and bulbouretral. As described by Lopes et al. (2015), the urinary vesicles were located in the pelvic cavity, in the middle sagittal position, demonstrating a pyriform shape. 


\section{CONCLUSION}

In view of the methodology used and the data obtained, it is accepted that the topography and syntopy of most of the organs present in the abdominopelvic cavity of the giant anteater are similar to the domestic animals, as well as in the other anteater species, except for kidneys and testicles. Future scientific research and records involving the abdominopelvic cavity of more specimens of the anteater are essential to consolidate the data obtained in the present work, aiming at the anatomical standardization of the species, without interferences of individual variations.

\section{REFERENCES}

ALSAFY, M.A.M.; EL-GENDY, S.A.A. Gastroesophageal junction of anatolian shepherd dog: a study by topographic anatomy, scanning electron and light microscopy. Vet. Res. Commun., v.36, p.63-69, 2012.

BARTMANN, C.P.; BEYER, C.; WISSDORF, $H$. Topography of the organs of the pelvic cavity and macroscopic and histologic findings of the sex organs of a male giant anteater (Myrmecophaga tridactyla) with regard to fertility. Dtsch. Tierarztl. Wochenschr., v.104, p.41-46, 1991.

BRAGA, F.G. Tamanduá-bandeira (Myrmecophaga tridactyla), espécie criticamente em perigo: uma preocupação no Estado do Paraná. Acta Biol. Parana, v.33, p.193-194, 2004.

BREMNER, C.G.; SHORTER, R.G.; ELLIS, F.H. Anatomy of feline esophagus with special reference to this muscular wall and phrenoesophageal membrane. J. Surg. Res., v.10, p.327-331, 1970.

CARVALHO, A.L.E.; MARTINS, L.L.; BOSSO, A.C.S.; MACHADO, M.R.F. Morfologia do fígado da paca (Cuniculus paca, Linnaeus 1766). Biotemas, v.25, p.109-115, 2012.

CASTRO, T.F.; DUMMER, R.J.; RICKES, E.M.; PEREIRA, M.A.M. Aspectos morfológicos, morfométricos e topográficos do aparelho digestório de Chinchilla lanígera. Braz. J. Vet. Res. Anim. Sci., v.47, p.86-94, 2010.
DYCE, K.M.; SACK, W.O.; WENSING, C.J.G. Tratado de anatomia veterinária. 4.ed. Rio de Janeiro: Elsevier, 2010. 872p.

FERREIRA, J.R.; SOUZA, A.L.R.; MORTOZA, A.R.; REZENDE, L.C. Vascularization of the small intestine in lesser anteaters, Tamandua tetradactyla (Xenarthra: Myrmecophagidae). Zoologia, v.28, p.488-494, 2011.

FREITAS, N.L.; PAULA, M.C.; PERRI, S.H.V.; FERRAZ, R.H.S. Morfologia do intestino delgado de capivara - Hydrochoerus hydrochaeris (Linnaeus, 1766). Braz. J. Vet. Res. Anim. Sci., v.45, p.122-130, 2008.

GETTY, R. Anatomia dos animais domésticos. 5.ed. Rio de Janeiro: Guanabara Koogan, 1986. 2 v. $1001 \mathrm{p}$.

GIRALDI, A.C.C.; AIRES, L.P.N.; RODRIGUES, R.F.; CRUVINEL, T.M.A.; MELO, A.P.F. Anatomia e segmentação pulmonar de tamanduá-bandeira (Myrmecophaga tridactyla - Linnaeus, 1758) de vida livre. Arq. Bras. Med. Vet. Zootec., v.69, p.22-18, 2017.

GULL, J.M.; STAHL, M.; OSMANN, C. et al. Digestive physiology of captive giant anteaters (Myrmecophaga tridactyla): determinants of faecal dry matter contente. J. Anim. Physiol. Anim. Nutr., v.99, p.565-576, 2015.

HOSSOTANI, C.M.S.; LUNA, H.S. Aspectos reprodutivos do tamanduá-mirim (Tamandua tetradactyla Linnaeus, 1758). Rev. Bras. Reprod. Anim., v.40, p.95-98, 2016.

JOHNSON-DELANEY, C.A. Exotic companion medicine handbook for veterinarians. Florida: Wingers Publishing, 1996.

KONIG, H.E.; LIEBICH, H.G. Anatomia dos animais domésticos: texto e atlas colorido. 6.ed. Porto Alegre: Artmed, 2016. 291p.

LOPES, E.R.; MORGADO, T.O.; MEIRELES, Y.S. et al. Ultrassonografia abdominal de tamanduás-bandeira (Myrmecophaga tridactyla Linnaeus, 1758) mantidos em cativeiro. Pesq. Vet. Bras., v.35, p.919-924, 2015.

LUBA, C.N.; BOAKARI, Y.L.; LOPES, A.M.C. et al. Semen characteristics and refrigeration in free-ranging giant anteaters (Myrmecophaga tridactyla). Theriogenol, v.84, p.1572-1580, 2015. 
MEDRI, I.M.; MOURÃO, G. A brief note on the sleeping habits of the giant anteater Myrmecophaga tridactyla Linnaeus (Xenarthra, Myrmecophagidae). Rev. Bras. Zool., v.22, p.1213-1215, 2005.

MEI, F.; HAN, J.; JIANG, Z.Y.; XIONG, C.J.; ZHOU, D.S. Plasticity of interstitial cells of cajal: a study in the small intestine of adult guinea pigs. Anat. Rec., v.292, p.985-993, 2009.

MIRETZKI, M.; BRAGA, F.G. Distribuição histórica e recente de Myrmecophaga tridactyla Linnaeus, 1758 (Pilosa, Myrmecophagidae) no Estado do Paraná, Brasil. Edentata, v.15, p.1626, 2014.

NOMINA Anatomica. New York: World Association of Veterinary Anatomists, 2012.

PINHEIRO, A.C.O.; LIMA, A.R.; CARVALHO, A.F.; PEREIRA, L.C.; BRANCO, É. Aspectos morfológicos macro e microscópicos do estômago de tamanduá-mirim (Tamandua tetradactyla). Arq. Bras. Med. Vet. Zootec., v.66, p.1089-1096, 2014.

REZENDE, L.C.; MONTEIRO, J.M.; CARVALHO, P.; FERREIRA, J.R.; MIGLINO, M.A. Morphology and vascularization of the gastric compartments in three-toed sloth (Bradypus torquatus Illiger, 1811). Int. J. Morphol., v.29, p.1282-1290, 2011.
RIBEIRO, P.R.Q.; SANTOS, A.L.Q.; RIBEIRO, L.A. et al. Movement anatomy of the gluteal region and thigh of the giant anteater Myrmecophaga tridactyla (Myrmecophagidae: Pilosa). Pesqui. Vet. Bras., v.36, p.539-544, 2016.

RIBEIRO, P.R.Q.; SANTOS, A.L.Q.; SOUZA, R.R. Anatomia óssea do cínglo pélvico, da coxa e da perna do tamanduá bandeira Myrmecophaga tridactyla (Myrmecophagidae: Pilosa). Biotemas, v.26, p.153-160, 2013.

SESOKO, N.F.; RAHAL, S.C.; BORTOLINI, Z. et al. Skeletal morphology of the forelimb of Myrmecophaga tridactyla. J. Zoo Wildl. Med., v.46, p.713-722, 2015.

SIQUEIRA, S.L.; LÁZARO-DA-SILVA, A. Contribuição à anatomia arterial do cólon sigmóide aplicável a operações de abaixamento. Arq. Gastroenterol., v.40, p.209-215, 2003.

SOUZA, A.L.R.; REZENDE, L.C.; MORTOZA, A.R.; FERREIRA, J.R. Modelo de suprimento sanguíneo do intestino grosso do tamanduá bandeira (Myrmecophaga tridactyla). Ciênc. Rural, v.40, p.541-547, 2010. 